\title{
Exploring recruitment \& selection practices in Pakistani SMEs
}

\author{
Abdul Raziq ${ }^{1 *}$, Aftab Ahmed Shaikh $^{2}$ \\ ${ }^{1}$ Faculy of Management Sciences, BUITEMS, Quetta \\ ${ }^{2}$ Faculty of Information \& Communication Technology, BUITEMS, Quetta \\ *Corresponding author E-mail: araziq85@gmail.com
}

Copyright $\odot 2015$ Abdul Raziq, Aftab Ahmed Shaikh. This is an open access article distributed under the Creative Commons Attribution License, which permits unrestricted use, distribution, and reproduction in any medium, provided the original work is properly cited.

\begin{abstract}
This study examines the adoption of recruitment \& selection practices in Pakistani small \& medium-size enterprises (SMEs). The study was conducted in the context of SMEs in the service and manufacturing sector in a Pakistani context. The primary data was collected through a survey of recruitment \& selection practices and as such the study is quantitative in nature. For the purpose of this study, a SME is defined as an organization employing between 20 and 250 employees with a small organization employing 20-100 employees and a medium sized organization employing 101 -250 employees. The target population of the study consisted of SMEs operating in the city of Karachi, Pakistan. Stratified random sampling method was applied to collect data from 331 SMEs. Cross tabulation was used to examine the level (low, moderate or high) of adoption of recruitment and selection practices in small and medium size firms. Chi square statistics was used to see the significant differences between small and medium-size firms regarding the use of recruitment and selection practices our findings indicate that there is a low level of adoption of recruitment and selection practices in Pakistani SMEs. There were no significant differences between small and medium-size firms regarding the use of majority of recruitment and selection practices.
\end{abstract}

\section{Introduction}

Small and Medium Enterprises (SMEs) play a significant role in the economic development of a country [1] both through employment creation and income generation [2]. Key to strengthening the SME sector is through the optimal utilisation of its human resources, technology and processes [3], [4]. Within SMEs each employee constitutes a larger percentage of the total workforce [5] emphasising the crucial importance of recruitment and selection practices which create an environment within which the skills and capabilities could be optimised and contribute to firm performance [6], [7]. Further to the latter, the focus of this paper is on exploring recruitment and selection practices in Pakistani SMEs.

Prior studies have indicated that there is no uniform definition of SMEs in Pakistan [8-10]. The Small and Medium Enterprise Development Authority (SMEDA), SME Bank, Pakistan Bureau of Statistics (PBS) and State Bank of Pakistan (SBP) have defined SMEs in different ways. For example, SMEDA defines a SME based upon the number of employees and total number of productive assets. The SME bank uses only total number of assets as the criterion. PBS takes into consideration only the number of employees. Whereas, SBP's definition of a SME is based on the nature of the business, number of employees, amount of capital employed and net sales value per annum. In this paper a SME is defined as: A small business is defined as an organisation employing one hundred or fewer employees, whereas medium-sized businesses are defined as ranging from 101 to 250 employees (the maximum size of employees are used as 250, as most of the official organisations in Pakistan use this size of employees in their definition of SMEs). Twenty employees are used as the lowest extremity for size because five out the six practices that the study focuses on are 
functional HRM practices and SMEs with a workforce with more than 20 employees are expected to have some kind of management structure [11].

Pakistan's economy, like that of many developing countries is a direct reflection of its SME sector [12]. According to Economic Census of Pakistan 2005 (this is the latest census in Pakistan); there are 3.2 million businesses in Pakistan. SMEs represent more than ninety percent of all private businesses and employ nearly 78 percent of the non-agriculture labour force in Pakistan [13]. SMEs' contribution to Pakistan's Gross Domestic Product is more than thirty percent. Additionally, the sector represents 25 percent of exports of manufactured goods and thirty-five percent in manufacturing value added. Almost 53 percent of all SME activity is in retail trade, wholesale, restaurants and the hotel sector. Twenty percent of SME activity is in industrial establishments and 22 percent in service provision [13].

However, regardless their economic importance, SMEs in Pakistan suffer from a variety of shortcomings, which have confined their ability to adjust to the economic liberalisation measures introduced by the GoP and their capacity to take full advantage of the rapidly growing world markets. These shortcomings include for example a focus on low valueadded products, absence of an effective business information infrastructure, an energy crisis, lack of strategic planning, low levels of financial literacy, unskilled human resources and non-aggressive lending strategies by banks [10], [14-17]. What makes a study on Recruitment and Selection practices in Pakistani SMEs is important? Pakistani SMEs are facing a big challenge in managing their human resources [18]. For example, the higher education institutions and the technical training infrastructure are the only two educational providers, both of which are not familiar with the unique requirements of SMEs nor are they equipped to deal with the challenges associated with SMEs. In addition, the limited financial resources of SMEs significantly limit their human resource development [14].

\section{Literature review}

Recruitment Practices: Recruitment is defined as 'the process of attempting to locate and encourage potential applicants to apply for existing or anticipated job openings'[19]. Recruitment strategies are directed to establishing a pool of qualified, skilled and experienced people for effective selection decisions [19]. Thus, 'recruitment is about sourcing the right people at the right time in the right place at the right price' (p. 15). According to Golhar and Desphande [7] external recruitment methods such as employment agencies and educational institutions are the key source of attracting fresh talent to the organisation.

Pfeffer [20] argues that firms can enhance their profitability by recruiting the right people in the first place. Moreover, previous research studies have found a positive relationship between effective recruitment and firm performance [e.g. [20], [21-23]. For instance, in a study of high performing hotels, Chand and Katou [23] found a high correlation between recruitment and profitability.

Most of the literature focusing on recruitment in SMEs, argue that small firms tend to use informal channels for employee recruitment (Marlow and Patton [24]. Carroll et al. [25] examined the recruitment methods of small firms and found little evidence of formal systematic procedures. For instance, they report that none of these firms use job analysis and all the firms in their study rely on word of mouth from the existing staff in their recruitment efforts. Some other studies [e.g. [26], [27], [28] also found 'word of mouth' as the most common method used in the recruitment process within the small business context.

In comparative studies of small and large firms, Deshpande and Golhar [29], and Golhar and Deshpande [7] reported that small and large firms prefer to hire employees from within organisations and engaged in practices such as job posting and biddings. In addition, these studies indicated that small firms tend not to use external recruitment methods such as employment agencies and educational institutions [29]. However, the study of Barrett and Mayson [30] found that growth-oriented small firms tend to adopt more formal recruitment practices in comparison to non-growing firms. In another study of small and larger firms, Barber et al. [31] found that small firms apply less formal recruitment practices in comparison to large firms. Moreover, they assert that larger firms are more oriented to set recruitment goals while small firms are more focused on performance outcome and turnover (p. 863). Heneman and Berkley [32] reported that small firms are using many different ways to attract employees rather than focusing on a set of best practices. However, they suggested that small firms can enhance their recruitment practices by having a HR manager or establishing a HR department.

Selection Practices: The selection process involves evaluating suitable applicants, their information from application forms, resumes, references and documents, tests undertaken and information collected from interviews [19]. According to Pfeffer [20], firms should emphasise important attributes that differentiate applicants. In addition, he argued that employees should be selected on the basis of basic ability and attitude rather than on technical skills, which can be easily acquired.

As in the case of recruitment, most of the small business literature argues that small firms tend to use less formal selection methods. According to Kotey and Slade [27] small firms tend to use more formal selection practices as they grow. They reported the use of the interview method as the predominant selection method at the operational level and review of applications, assessment of qualifications, and the use of references at the managerial level (p. 26). Golhar and Deshpande [7] found one-on-one interviews as a well-accepted selection method in both large and small firms. However, written tests and panel interviews were most often used by larger firms (pp. 35-6). Moreover, Bartman et al. 
[33] in a study of 498 small businesses noted more informal and reactive approaches to selection practices by small firms. They reported unstructured interviews as the common selection method in small firms (p. 347). Their results are consistent with Marlow and Patton [24]. However, Rowden [34] studied successful small firms in the US and found more formal selection practices with a focus on appropriate technical skills and positive work ethics.

Regarding the link between selection and firm performance, Delaney and Huselid, [22] found a positive relationship between selective staffing and firm performance. Chand and Katou [23] also noted a high correlation between selection and profitability.

In view of the discussion above the objective of this paper is to explore the current prevalence of Recruitment and Selection practices in Pakistani SMEs? The research objective focuses on providing descriptive trend data on the prevalence of Recruitment and Selection practices in SMEs. In other words, collectively, which practices are most common and which are marginalised among our sample of SMEs?

\section{Methodology}

\subsection{Sample}

To examine the explore Recruitment and Selection practices in Pakistani SMEs; a large scale questionnaire survey was conducted in the industrial city of Karachi, Pakistan. The sampling frame was based on the following data bases: Karangi Association of Trade and Commerce (KATI) Karachi; Karachi Chamber of Commerce and Industry (KCCI) and Jamal's Yellow pages, Pakistan. However, the three databases were not specifically designed for SMEs. Nevertheless, these data bases were deemed to be the most reliable and updated databases in Karachi, Pakistan. A random sample of 703 firms was selected. The population was stratified by industry sector (manufacturing and services). These two sectors were selected based on their economic importance [35] and their likelihood to have some management structure.

\subsection{Data collection}

It was not possible to collect data in the 'normal' postal survey method and the researcher had to utilise a team of 10 individuals to collect data from the selected sample owing to the following reasons: (1) security was an issue, (2) data collection commenced shortly after a major flood occurred in Pakistan, (3) SME managers who represented the target sample may not have a good command of the written English language, and (4) education levels of SME managers are low. The data collection team consisted of postgraduate research students at University of Karachi. The researcher is a senior university lecturer and was able to identify suitable individuals. The researcher provided a 2-day training course to the data collection team on the content of the survey itself and collection of the data through filling out the questionnaires by face-to-face collaboration with survey respondents. The team was continuously monitored by the researcher. To seek participation from the selected organisations, the research team contacted the organisations first by telephone and through their personal interaction with the management of trade associations. The selected organisations were first asked about the size of their workforce and the number of employees they employ since the databases were not designed specifically for SMEs (as mentioned above). If the selected organisation fulfilled the requirements of the definition of a SME (20-250 employees), the SME manager was invited to participate in this survey. In cases where a particular organisation declined the invitation, it was replaced by contacting another organisation in the same industry as per the sampling frame.

A total of 703 firms were selected, contacted by phone and invited to participate in this survey. Of these firms, 357 SMEs (50.78 percent response rate) accepted the invitation to fill out the survey questionnaire. Most of the respondents who agreed requested that the researcher visit their organisations personally, and only a few respondents (from services sector) agreed to fill questionnaire by email (five firms). In each case, the procedure was explained to the respondents about how to fill the questionnaire out and they were assured that their responses would be treated as strictly confidential. The questionnaires were filled out by either the owner or human resource manager in each firm. In the end, 357 questionnaires were collected. Of the 357 responses collected from SMEs, 243 were from the manufacturing sector and 114 responses from the service sector. A total of 227 responses were collected from small firms (145 from manufacturing and 82 from service sector) and 130 responses from medium sized firms (98 from manufacturing and 32 from service sector).

\subsection{Measures}

Questionnaire: The survey instrument was adapted from Wiesner et al. [11] and was applied in the Pakistani context of this study. In addition, the language of survey questionnaire was English as this language is commonly used in most of the Pakistani organisations. This survey questionnaire was originally developed and validated by Wiesner et al. [11] for the study of 'high performance management practices' in Australian SMEs during 2007. The content validity and reliability of the updated questionnaire were also addressed. The content validity of the revised questionnaire was 
determined by interviewing and presenting the questionnaire to 10 SME owner-managers in different SMEs within Karachi, Pakistan. In addition, five managers from SMEDA (Small and Medium Enterprise Development Authority Pakistan) were invited to comment on the questionnaire. This was followed by a pilot survey conducted in 20 different SMEs in Karachi, Pakistan. On the basis of the interview feedback and results from the pilot survey, the survey instrument was revised and presented to the selected sample. A reliability analysis indicated a Cronbach Alpha Coefficients of between 0.62 and 0.80 for each section.

\section{Results}

Cross tabulation was used to examine the level (low, moderate or high) of adoption of recruitment and selection practices in small and medium size firms. Chi square statistics was used to see the significant differences between small and medium-size firms regarding the use of recruitment and selection practices. It is evident from Table 1 that there is low level of adoption of formal recruitment and selection practices. Consistent with Wiesner, McDonald and Banham (2007) we defined a low level of adoption of recruitment and selection practices are employed where 30 percent or less of SMEs have adopted that practice, moderate level of adoption falls between 31 and 69 percent and high level of adoption of recruitment and selection practices are occurred where 70 or more firms have employed that practice.

The recruitment practices in Table 1 indicate that most of SMEs (more than 70 percent) relied on informal recruitment practices such as referrals by employees, referral from other sources and walk-ins. About one third of SMEs were using written job description. Only 38 percent were using newspaper advertising, 13 percent of SMEs were utilising internet recruitment, and 3 percent reported educational institution recruitment services, and recruitment consultants. In addition, only one percent of SMEs have chosen Radio, Television or Magazine advertisement media. Moreover, firm size was not significantly affecting the adoption of recruitment practices with only Direct mail method was more prevalent in medium-size firms compare to small firms.

With regard to selection practices, less than 50 percent of SMEs were utilising application forms. One-on-one interview and unstructured interview methods were the dominant selection method in more than 80 percent of SMEs. However, formal practices were significantly higher in medium sized firms compare to small firms (8 out of 16 practices). Moreover, services-based SMEs have significantly adopted more formal selection practices in comparison to manufacturing firms (11 practices).

Table 1: The Prevalence of Recruitment and Selection Practices in Pakistani SMEs

\begin{tabular}{|c|c|c|c|c|c|}
\hline & & $\%$ & $\mathrm{n}$ & $\begin{array}{l}\text { Small firms } \\
\%\end{array}$ & $\begin{array}{l}\text { Medium-size firms } \\
\%\end{array}$ \\
\hline & Recruitment Practices & & & & \\
\hline 1 & Internal recruitment methods & 99 & 327 & 99 & 99 \\
\hline 2 & Job analysis & 72 & 238 & 72 & 72 \\
\hline 3 & Job analysis computer software & 3 & 11 & 2 & 6 \\
\hline 4 & Written job description/specification & 37 & 121 & 33 & 44 \\
\hline 5 & Role specification & 66 & 217 & 64 & 68 \\
\hline 6 & Employee requisition forms & 31 & 103 & 28 & 38 \\
\hline 7 & Advertising via bulletin board/news letter & 10 & 32 & 10 & 10 \\
\hline 8 & Internal data base search for internal applicants & 24 & 79 & 22 & 27 \\
\hline 9 & Newspaper advertising & 38 & 124 & 38 & 36 \\
\hline 10 & Government employment agency & 0 & 0 & 0 & 0 \\
\hline 11 & Private employment agency & 9 & 29 & 10 & 7 \\
\hline 12 & Referrals by employees & 87 & 287 & 87 & 86 \\
\hline 13 & Referral from other sources & 79 & 260 & 79 & 79 \\
\hline 14 & Walk-ins & 71 & 235 & 75 & 65 \\
\hline 15 & Radio advertising & 1 & 2 & 0 & 2 \\
\hline 16 & Television advertising & 1 & 2 & 0 & 2 \\
\hline 17 & Internet recruitment & 13 & 42 & 13 & 13 \\
\hline 18 & Direct mail & 21 & 68 & 14 & $32 *$ \\
\hline 19 & Advertising in magazines & 1 & 2 & 1 & 1 \\
\hline 20 & Educational institutions' recruitment services & 3 & 10 & 3 & 3 \\
\hline 21 & Professional associations & 0 & 0 & 0 & 0 \\
\hline 22 & Recruitment consultants & 3 & 10 & 3 & 3 \\
\hline 23 & $\begin{array}{l}\text { Recruitment strategy specifically targeting older workers } \\
\text { Selection Practices }\end{array}$ & 1 & 2 & 1 & 0 \\
\hline 24 & Application forms & 49 & 160 & 43 & $59 *$ \\
\hline 25 & One-on-one interviews & 90 & 298 & 92 & 87 \\
\hline 26 & Unstructured interviews & 83 & 272 & 84 & 79 \\
\hline 27 & Structured interviews & 53 & 177 & 50 & 60 \\
\hline
\end{tabular}


Panel interviews

Behaviourally based interviews

Work samples

Written reference checks

Verbal (telephone) reference checks

Psychological tests

Assessment centre

Use consultants in selection process

Line manager makes selection decision

Other managers/employees have input in selection design

Other employees have input in final selection decision

External consultant have input in the final selection decision

$\begin{array}{lll}46 & 152 & 39 \\ 29 & 95 & 21 \\ 51 & 169 & 46 \\ 24 & 80 & 23 \\ 18 & 57 & 21 \\ 3 & 10 & 3 \\ 10 & 33 & 7 \\ 4 & 12 & 3 \\ 33 & 109 & 35 \\ 27 & 89 & 33 \\ 12 & 39 & 16 \\ 1 & 4 & 1\end{array}$

$60 *$

$42 *$

$60^{*}$

27

$11^{*}$

3

$16^{*}$

4

29

$16^{*}$

4*

2

\section{Discussion}

This paper examines the adoption of recruitment and selection practices in Pakistani SMEs. Within the selection component, some contradictions occurred with regard to some sub- components. Formal practices such as Application form, Panel interviews and behaviourally based interviews practices were used to a significantly greater extent by medium firms whereas small firms employed informal selection practices to significantly greater extent. The latter finding is consistent with the results of [36]. The other selection practices such as Work samples, written and verbal reference check, Assessment centers and External input in the selection process show no differences with regard to firm size. Such practices were used to a minor extent in both small and medium firms despite acknowledged ability to enhance the general validity and acceptability of selection decisions [37]. Jameson has found that employing more formal sophisticated methods may enhance SMEs' ability to improve the appropriateness of appointments as a means to lower employee turnover [38]. These more sophisticated selection practices are relatively more costly and time consuming to implement in small firms than in larger firms [39,40] especially as SMEs often may not have managerial resources and expertise in the area of selection and other HRM activities [6], [41-43]. Furthermore, these practices are normally sourced external to the SME owing to the mentioned lack of expertise within the SME.

Within the Pakistani context, specific triggers of this lack of $\mathrm{f}$ adoption of formal recruitment and selection practices, could be the lack of resources [44], [45], current financial and economic problems [17], a lack of awareness about the benefits of such practices (as discussed above) and also a lack of training, education, and entrepreneurial skills which are integral to the current characteristics of the respondent SMEs [46].

\section{Conclusion}

A low level of adoption of formal recruitment and selection practices were found in Pakistani SMEs. There were no significant differences between small and medium-size firms regarding the use of recruitment and selection and practices. Like any other research, this study is not without its limitations. First, the data has been obtained from a single person in the form of owners/managers who rated their recruitment and selection practices in their organisations [47]. However, collecting data from owners/mangers, managing directors or the chief executive officer (CEO) as the self-reporting person is a common approach since CEOs are well informed about all strategic and operational activities within the organisation [48] Within the SME context it is specifically appropriate since the SMEs owner/manager is the key person who run most of the affairs of business and take most of the strategic decisions [9].

This study has been conducted in the Pakistani context and the data for this research study was collected from SMEs in service-based and manufacturing firms in a single city (Karachi) within Pakistan. Thus, caution should be applied for interpreting the generalizability of results. However, Karachi is the biggest industrial city of Pakistan. It contributes 25 percent to national GDP. It also shares 65 percent in national revenue such as federal and provincial taxes, customs and surcharges [49]. Furthermore, the data was collected from 13 major industries (within the two major categories of manufacturing and services). Future research including other parts of Pakistan (rural and urban) would add significantly to the generalizability of the results within Pakistan.

Finally, the survey in this study was conducted at a single point in time. In view of the significant difficulties experienced in Pakistan during the conduct of this study, there is the risk of potential distortion of the responses because respondents may have viewed their world and reality only in the light of whatever seemed important to them at that specific time. This limitation could be overcome by conducting longitudinal studies in the future (Barnes, 2002).

\section{References}

[1] N. Bacon and K. Hoque, "HRM in the SME sector: valuable employees and coercive networks," International Journal of Human Resource Management, vol. 16, pp. 1976-1999, 2005. http://dx.doi.org/10.1080/09585190500314706. 
[2] T. Lange, M. 1. Ottens, and A. Taylor, "SMEs and barriers to skills development: A Scottish perspective," Journal of European Industrial Training, vol. 24, p. 5, 2000. http://dx.doi.org/10.1108/03090590010308219.

[3] J. B. Barney, "Firm resources and sustained competitive advantage," Journal of Management, vol. 17, pp. 99-120, 1991. http://dx.doi.org/10.1177/014920639101700108.

[4] M. A. Huselid, "The impact of HRM on turnover, productivity, and corporate financial performance," Academy of Management Journal, vol. 38, pp. 635-672, 1995. http://dx.doi.org/10.2307/256741.

[5] R. Hill and J. Stewart, "Human resource development in small organizations," Journal of European Industrial Training, vol. 24, pp. 105-117, 2000. http://dx.doi.org/10.1108/03090590010321070.

[6] J. S. Hornsby and D. F. Kuratko, "Human Resource Management in U.S. Small Businesses: A Replication and Extension," Journal of Developmental Entrepreneurship, vol. 8, p. 73, 2003.

[7] D. Y. Golhar and S. P. Deshpande, "HRM Practices of Large and Small Canadian Manufacturing Firms," Journal of Small Business Management, vol. 35, pp. 30-38, 1997.

[8] S. W. S. B. Dasanayaka, "SMEs in globalized world: A brief note on basic profiles of Pakistan's small and medium scale enterprises and possible research directions," Business Review, vol. 3, pp. 69-76, 2008.

[9] A. Rana, J. Khan, and U. Asad, "The SME pulse: An exploratory study of the performance of SMEs in Pakistan and the characteristics of successful firms," Small and Medium Enterprise Center, Lahore University of Management Sciences., 2007.

[10] I. Mustafa and F. M. Khan, "Small and Medium Enterprises in Pakistan," South Asian Journal, vol. 9, 2005.

[11] R. Wiesner, J. McDonald, and H. C. Banham, "Australian small and medium sized enterprises (SMEs): A study of high performance management practices," Journal of Management and Organization, vol. 13, pp. 227-248, 2007. http://dx.doi.org/10.5172/jmo.2007.13.3.227.

[12] M. Khalique, A. H. B. M. Isa, and J. A. Nassir Shaari, "Challenges for Pakistani SMEs in a Knowledge-Based Economy," Indus Journal of Management \& Social Sciences, Vol. 5, No. 2, 2011, 2011.

[13] PBS. (2011, 9 January). Economic Census of $\quad$ Pakistan $2005 . \quad$ Available: <http://www.statpak.gov.pk/depts/fbs/publications/nec2005/nec2005.html>.

[14] F. Bari, A. Cheema, and Ehsan-ul-Haque, "SME development in Pakistan: Analyzing the constraints to growth. ," Pakistan Resident Mission Working Paper No.3, Islamabad: ADB., 2005.

[15] S. Khawaja, "Unleashing the growth potential of SMEs in Pakistan through productivity enhancement," Pakistan Development Forum-2006, 2006.

[16] C. 1. Rohra and I. A. Panhwar, "The role of SMEs towards exports in Pakistan economy," Australian Journal of Basic and Applied Sciences, vol. 3, pp. 1070-1082, 2009.

[17] SBP, "Annual Report 2009-2010," State Bank of Pakistan, Karachi2010.

[18] SMEDA. (2007, September 19). SME Policy. Available: http://www.smeda.org/downloads/smepolicy2007.pdf

[19] R. Compton, E. Morrissey, and A. Nankervis, Eds., Effective recruitment and selection Practices. Australia: CCH Australia Limited, 2009, p.^pp. Pages.

[20] J. Pfeffer, "Seven practices of successful organizations," California Management Review, vol. 40, pp. 96-123, 1998. http://dx.doi.org/10.2307/41165935.

[21] A. A. Katou and P. S. Budhwar, "The effect of human resource management policies on organizational performance in Greek manufacturing firms," Thunderbird International Business Review, vol. 49, pp. 1-35, 2007. http://dx.doi.org/10.1002/tie.20129.

[22] J. T. Delaney and M. A. Huselid, "The impact of human resource management practices on perceptions of organizational performance," Academy of Management Journal, vol. 39, pp. 949-969, 1996. http://dx.doi.org/10.2307/256718.

[23] M. Chand and A. A. Katou, "The impact of HRM practices on organisational performance in the Indian hotel industry," Employee Relations, vol. 29, pp. 576-594, 2007. http://dx.doi.org/10.1108/01425450710826096.

[24] S. Marlow and D. Patton, "Managing the Employment Relationship in the Smaller Firm: Possibilities for Human Resource Management," International Small Business Journal, vol. 11, pp. 57-64, 1993. http://dx.doi.org/10.1177/026624269301100404.

[25] M. Carroll, M. Marchington, J. Earnshaw, and S. Taylor, "Recruitment in small firms: Processes, methods and problems," Employee Relations, vol. 21, pp. 236-250, 1999. http://dx.doi.org/10.1108/01425459910273080.

[26] C. Cassell, S. Nadin, M. Gray, and C. Clegg, "Exploring human resource management practices in small and medium sized enterprises," Personnel Review, vol. 31, pp. 671-692, 2002. http://dx.doi.org/10.1108/00483480210445962.

[27] B. Kotey and P. Slade, "Formal Human Resource Management Practices in Small Growing Firms," Journal of Small Business Management, vol. 43, pp. 16-40, 2005. http://dx.doi.org/10.1111/j.1540-627X.2004.00123.x.

[28] P. Connolly and G. McGing, "High performance work practices and competitive advantage in theIrish hospitality sector," International Journal of Contemporary Hospitality Management, vol. 19, pp. 201-210, 2007. http://dx.doi.org/10.1108/09596110710739903.

[29] S. P. Deshpande and D. Y. Golhar, "HRM practices in large and small manufacturing firms: A comparative study," Journal of small Business Management, pp. 49-56, 1994.

[30] R. Barrett and S. Mayson, "Human resource management in growing small firms," Journal of Small Business and Enterprise Development, vol. 14, pp. 307-320, 2007. http://dx.doi.org/10.1108/14626000710746727.

[31] A. E. Barber, M. J. Wesson, O. M. Roberson, and M. S. Taylor, "A tale of two job markets: Organizational size and its effects on hiring practices and job search behaviour," Personnel Psychology, vol. 52, pp. 841-867, Winter99 1999.

[32] I. I. I. H. G. Heneman and R. A. Berkley, "Applicant Attraction Practices and Outcomes among Small Businesses," Journal of small Business Management, vol. 37, pp. 53-74, 1999.

[33] D. Bartman, P. A. Lindley, L. Marshall, and J. Foster, "The recruitment and selection of young people by small businesses," Journal of Occupational \& Organizational Psychology, vol. 68, pp. 339-358, 1995. http://dx.doi.org/10.1111/j.2044-8325.1995.tb00592.x.

[34] R. W. Rowden, "High performance and human resource charcteristics of successful small manufacturing and processing companies," Leadership \& Organizational Development Journal, vol. 23, pp. 79-83, 2002. http://dx.doi.org/10.1108/01437730210419206.

[35] Economic Survey. (2010-11). Pakistan Economic Survey 2010-11. Overview of the Economy. Available: http://www.finance.gov.pk/survey_1011.html.

[36] J. De Kok, L. M. Uhlaner, and R. A. Thurik, "Human resource management with small and medium sized enterprises firms: Facts and explanations," Eramus university, Rotterdam2003.

[37] N. Heraty and M. Morley, "In search of good fit: policy and practice in recruitment and selection in Ireland," Journal of Management Development, vol. 17, pp. 662-685, 1998. http://dx.doi.org/10.1108/02621719810244490.

[38] S. M. Jameson, "Recruitment and training in small firms," Journal of European Industrial Training, vol. 24, pp. 43-49, 2000. http://dx.doi.org/10.1108/03090590010308255.

[39] G. M. McEvoy, "Small business personnel practices," Journal of Small Business Management, vol. 22, pp. 1-8, 1984.

[40] R. S. Reid and R. I. D. Harris, "The determinants of training in SMEs in Northern Ireland," Education \& Training, vol. 44, pp. 443-450, 2002. http://dx.doi.org/10.1108/00400910210449286.

[41] G. N. Chandler and G. M. McEvoy, "Human Resource Management, TQM, and Firm Performance in Small and Medium-Size Enterprises," Entrepreneurship: Theory \& Practice, vol. 25, p. 43, Fall2000 2000. 
[42] B. S. Klaas, J. McClendon, and T. W. Gainey, "Managing HR in the Small and Medium Enterprise: The Impact of Professional Employer Organizations," Entrepreneurship: Theory \& Practice, vol. 25, p. 107, Fall2000 2000.

[43] R. McLarty, "The Skills Development Needs of SMEs and Focus on Graduate Skills Application," Journal of Applied Management Studies, vol. 8, p. 103, 1999.

[44] N. Kaya, "The impact of human resource management practices and corporate entrepreneurship on firm performance: evidence from Turkish firms," The International Journal of Human Resource Management, vol. 17, pp. $2074 \quad-\quad 2090,2006$. http://dx.doi.org/10.1080/09585190601000204.

[45] H.-A. Shih, Y.-H. Chiang, and C.-C. Hsu, "Can high performance work systems really lead to better performance?," International journal of Manpower, vol. 27, pp. 741-763, 2006. http://dx.doi.org/10.1108/01437720610713530.

[46] HafizUllah, B. Shah, F. S. U. Hassan, and T. Zaman, "The impact of Owner Psychological Factors on Entrepreneurial Orientation: Evidence from Khyber Pakhtunkhwa-Pakistan," International Journal of Education and Social Sciences, vol. 1, 2011.

[47] B. Gerhart, P. M. Wright, G. C. McMahan, and S. A. Snell, "Measurement error in research on human resources and firm performance: How much error is there and how does in influence effect size estimates?," Personnel Psychology, vol. 53, pp. 803-834, Winter2000 2000.

[48] T. S. Frost, J. M. Birkinshaw, and P. C. Ensign, "Centres of excellence in multinational corporations," Strategic Management Journal, vol. 23, p. 997, 2002. http://dx.doi.org/10.1002/smj.273.

[49] CDGK. (2011, April 28, 2011). City district government Karachi: Economy and development. Available: http://221.132.118.186/cdgk/Home/AboutKarachi/Economy/tabid/271/Default.aspx. 